\title{
THE FINANCIAL PERFORMANCE OF BLACK OWNED GROCERY SHOPS IN TOWNSHIPS IN SOUTH AFRICA
}

\author{
Norman CHILIYA \\ Gorge HERBST \\ University of Fort Hare, South Africa \\ Mornay Roberts -LOMBARD \\ University of Johannesburg, South Africa
}

\begin{abstract}
This study investigates the financial performance of black owned grocery shops in Mdantsane in South Africa. To achieve this objective, the research hypothesised that variables that impact on the performance of grocery shops are amongst others, bad debts and excessive withdrawals. It was also hypothesised that a lack of sufficient funds implies that grocery shops cannot embark on vigorous marketing efforts and this erodes profitability. The study is important because grocery shops in townships being a source of income for most of the black population it has been given less attention. The results indicate that management of grocery shops have to pay special attention to asset management in order to achieve an acceptable turnover relative to assets. It is often the case that better asset management sets free some of the funds tied up in a business for creating greater turnover, better discounts or expansion. It is, also, imperative that the management of small firms improve their managerial skills on aspects of financing, financial information preparation, and the calculation of capital requirements.
\end{abstract}

\section{INTRODUCTION}

Financial performance refers to a management initiative to upgrade the accuracy and timeliness of financial information. Meeting requirements and standards, while supporting day-to-day operations, is central to this initiative. Areas of emphasis include reducing erroneous payments and strengthening the management of government-held assets (Anon., 2006a). Cant and Brink (2003:5) highlight that financial management is a crucial field within the endogenous environment of SMEs that presents numerous potential obstacles. Management competence is often determined by the availability of management and financial information. Lack of financial sources is often reported as the major obstacle experienced by businesses. Financial issues important for business success are capital requirements, bookkeeping, financial planning, financial control, management of working capital and income generation. In the light of this the study intends to explore these issues in detail.

\section{PROBLEM STATEMENT}

The rapidly growing grocery retail sector, in South Africa, is under intense pressure due to limited resources and services. According to Rode Property Economists, Consultants and Valuers (2004) $80 \%$ of township retailers have left regular employment to take up opportunities in the townships. High and growing unemployment in the mainstream economy motivates an increasing number of individuals to enter the informal sector, typically, as street vendors and other service providers. However, the livelihoods, wages and working conditions within the sector are rarely adequate to sustain a basic lifestyle for even a small number of traders. The flooded market results in intense competition and high tension as sellers compete for scarce customers.

The Minister of Finance in South Africa, Mr. Trevor Manuel, highlighted that shop traders' battle with hawkers and street sellers over space, and the fierce competition frequently lead to violence. In almost all the townships, butcheries, bakeries, clothing and grocery shops, owned by Asian or Middle Eastern 
foreign investors, have sprung up. The local businessmen are not happy that foreign investors should venture into businesses that should be owned or managed by South Africans (South African Government, 1995). A businessman in Soweto echoed that "if foreign investors start running grocery shops and butcheries and sell amafongkong (imported clothing), what will South Africans do?" (Competition Tribunal South Africa, 2000). Established retailers such as Shoprite have also entered the township market which will increase the level of competition for the grocery shops in the township area.

In the light of serious competition indicated above the study intends to contribute to a more comprehensive understanding of variables that impinges on the financial performance of grocery shops in Mdantsane. A more in-depth study of the financial performance of black owned grocery shops is required to answer the following questions, namely:

$>$ Is it possible to establish the performance of small businesses in the grocery shop sector in South African townships over a specific period of time?;

$>$ To what extent is the financial performance of the small business in the grocery market sector influenced by the behaviour of the owners?; and

$>$ Is the performance of grocery shops affected by the lack of availability of funds?

\section{LITERATURE REVIEW}

A review of the literature reveals several ways to assess financial performance. An organization's performance can be measured using financial measures (e.g. profitability, sales growth etc), operational indicators (e.g. market share), share price or using a combination of factors. Within the domain of financial performance, numerous financial ratios are available, and the ratios fall into four major categories: profitability ratios, cost ratios, growth ratios and valuation ratios (Venktraman and Vasudevan, 1986:801).

\section{Profitability Ratios}

Maximising the wealth of the shareholders or owner's interest is an acceptable criterion. This implies a denominator that consists only of owners (risk bearer) capital, whereas the numerator reflects the net earnings attributable to the owners. Correira et al. (2003:ch1, p11) note that the objective of financial management is the maximisation of wealth; a structured analysis should aim towards measuring how effectively this objective is achieved. The return on owner investment indicates, to the entrepreneur, how many cents he earns in a year for every rand of investment.

Return on assets, also known as the return on investment, measures the profitability of a firm as a whole in relation to the total assets employed. It illustrates the overall effectiveness of management in generating profit with its available assets. It is calculated by dividing earnings before interest and taxes by the total assets. Other definitions of earnings include earnings before interest, but after taxes and earnings after interest and taxes. However, earnings before interest and taxes are used as the numerator because the return on all the firm's assets, and not just equity investment, is measured. In addition, since all assets are financed by both the shareholders and creditors, the ratio should measure the productivity of assets in providing returns to both classes of investors (Correia et al., 2003:191).

Formula 1.1, below, depicts the calculation of return on assets.

Formula 1.1 Calculation of return on assets

Return on assets $=$ Earnings before interest and taxes (EBIT) / Total assets

Source: Adapted from Gitman (2003:65)

This research uses return on equity (ROE) depicted in the formula 1.2 below, below, as the overall indicator of success. While profit maximisation would not be a primary objective, the return on equity is the bottom line measure of performance. It illustrates the effectiveness of financial leverage. A high return on equity indicates that borrowed funds have been profitably employed. This implies that a firm can comfortably meet its interest commitment while still retaining profit for owners. This is measured by formula 1.2 below.

Formula 1.2 Calculation of return on equity (ROE)

ROE $=$ Net Earnings after Tax/ Owners Interest

Source: Adapted from Gitman (2003:65)

However, considering that most grocery shops owned by black businessmen lack sufficient capital, borrowed capital could become an important component in the capital structure of the shops.

In order to measure the favourable or unfavourable effect of financial leverage, it is suggested that formula 1.3 be used.

\section{Formula 1.3 Effect of financial leverage}

Net Earnings Before tax / Total Assets > Before Tax Interest rate on debt

Source: Adapted from Gitman (2003:65) 
The combined use of the aforementioned two criteria enable the researcher to investigate and assess the impact of financial leverage as illustrated by (Correira et al., 2003:ch.20, p.10). In order for a business to achieve a positive financial leverage, liquidity and solvency must also be considered.

\section{Liquidity ratios}

The liquidity of a business is measured by its ability to satisfy its short-term obligations as they come due. This implies that a liquid firm is one that is able to raise cash when it is needed. This ability of the firm viz to be liquid is called technical solvency. Legal insolvency occurs when a firm's total liabilities exceed a fair valuation of its total assets. This means that the net worth of the firm is negative. Money market securities are an excellent source of asset liquidity. A potential liability e.g. unused available credit, as in a bank overdraft or revolving credit, also provides liquidity. For example, if a firm has a revolving credit of R200 000 and is currently borrowing only R50 000, it has R150 000 of liquidity from this borrowing source. It follows that a firm with a credit of R200 000 that is borrowing R50 000 has more liquidity than a firm with the same amount of credit, but borrowing the full R200 000. To the extent that a firm has large investments in assets that are readily convertible into cash and has a large potential for borrowing, it is liquid (Steinhoff and Burger, 1996:256).

Steinhoff and Burger (1996:256) further argue that there are two aspects of liquidity namely planned liquidity and protective liquidity. An entrepreneur has to forecast cash needs and plan how those needs are to be met - through reductions in assets or the issuance of shares (as in venture capital). Protective liquidity is the ability to meet unexpected cash demands. Unexpected cash demands are net cash outflows which are greater than the forecasted cash flow. Unexpected cash demands can arise for many reasons. In some cases cash can be needed to undertake unexpected investment opportunities. The inability to raise sufficient cash to undertake these investments results in the forgone profits. It is against this background that ratios that indicate the financial position, such as current ratio and quick ratio, are elaborated on subsequently.

The current ratio is calculated by dividing current assets by current liabilities. Current assets normally include cash, accounts receivable and stocks, while current liabilities consist of accounts payable and accrued expenses. The ratio indicates the extent to which the claims of short term creditors are covered by assets that can be translated into cash in the short term (Correira et al., 2003:ch20, p.10). The calculation is given by formula 5.4 , below:

Formula 5.4 Calculation of current ratio

Current ratio $=$ Current assets

Current liabilities

Source: Adapted from Gitman (2003:65)

In other cases, cash may be needed because of unexpected outflows. For example, a sudden increase in the price of inputs such as production material (Steinhoff and Burger, 1996:257). Cash may be required because cash inflows are less than anticipated for example, a strike that stops production, a slowdown in collections due to a recession in the economy, a breakdown in a critical manufacturing step that cannot be fixed quickly or a technological breakdown that causes prices to drop dramatically. Given the general uncertainty regarding cash flows, entrepreneurs should maintain a conceivable amount of liquidity. Entrepreneurs should commit credit well above the amount they expect to be needed. Hence, it is advisable to use the quick ratio, since it takes longer to translate stock into cash. It is a useful measure of the firm's ability to pay off short term obligations without relying on the sale of stocks (Correira et al., 2003:ch20, p.10). The quick ratio is calculated by deducting stock from the current assets and dividing the remainder by current liabilities, as indicated by formula 1.5, below.

Formula 1.5 Calculation of quick ratio

Quick ratio $=$ Current assets- stock / Current liabilities

Source: Adapted from Gitman (2003:65)

\section{Solvency ratios}

Solvency refers to liquidity in the long-term, that is, a firm's ability to pay its long-term debt. The more solvent a firm, the better protected its owner is from losing his investments (Correira et al., 2003: $\operatorname{ch} 20$, p.10). To measure this protection, entrepreneurs should use, as a yardstick the debt ratio, debt equity ratio, times interest earned ratio and the Altman model. These ratios and the Altman model are depicted as follows:

Formula 1.6 Calculation of debt ratio

Debt ratio $=$ Total Liabilities $/$ Total assets

Source: Adapted from Gitman (2003:65)

Formula 1.7 Calculation of debt to equity ratio

Debt to Equity $=$ Total debt $/$ Total Equity

Source: Adapted from Gitman (2003:65) 
Formula 5.8 Calculation of times interest earned ratio Times Interest Earned $=$ Operating Profit before Tax / Interest expense

Source: Adapted from Gitman (2003:65))

\section{Altman Model}

Altman (1968:589) introduced the Multiple Discriminant Analysis (MDA) to develop a predictive model for insolvency of firms with a high degree of accuracy. This technique, based on regression analysis, establishes coefficients for the ratios that minimise misclassification. A major reason for the high rate of financial distress of firms is attributed to the effect of heavy debt burdens. Using a sample of 66 manufacturing companies ( 33 failed and 33 successful) Altman's regression model achieved an accuracy of $95 \%$. Altman argues that ratios alone cannot provide the complete story and can be misleading when viewed in isolation. He therefore combined several ratios with statistical techniques to arrive at a single numeric score for the financial health of companies called the $\mathrm{Z}$ score. This original $\mathrm{Z}$ score was revised by Altman in 1983 to incorporate small firms that are not listed on the Stock Exchange. This model Altman called Z. The Altman regression model that predicts the $\mathrm{Z}$ score for small manufacturing firms is explained in equation 7.2 below

Formula 5.9 Calculation of the $\mathrm{Z}$ score

$\mathrm{Z}=0.717(\mathrm{X} 1)+0.847(\mathrm{X} 2)+3.107(\mathrm{X} 3)+0.420(\mathrm{X} 4)$ $+0.998(X 5)$

Where: $\mathrm{X} 1$ = Working capital / Total assets

$\mathrm{X} 2=$ Retained earnings $/$ Total assets

$\mathrm{X} 3$ = Earnings before interest and taxes / Total assets

$$
\begin{aligned}
& \mathrm{X} 4=\text { Book value of equity/ Total assets } \\
& \mathrm{X} 5=\text { Sales } / \text { Total assets }
\end{aligned}
$$

$X 1$ represents the ratio of working capital to total assets. This is the $\mathrm{Z}$ score which is considered to be a reasonable predictor of the increasing financial problem of a firm. A firm that experiences repeated losses usually suffers a reduction in working capital relative to its total assets.

$X 2$ represents the ratio of retained earnings to total assets. This is a $\mathrm{Z}$ score component that provides information on the extent to which a firm has been able to reinvest its earnings in itself.

$\mathrm{X} 3$ represents the ratio of earnings before interest and taxes to total assets. The ratio adjusts for tax factors and also makes adjustments for leveraging due to borrowings. These adjustments allow more effective measurements of a firm's utilization of assets.

$\mathrm{X} 4$ represents the ratio of book value of equity to total assets. This ratio provides an indicator of how much a firm's assets can decline in value before debt exceeds assets.

$\mathrm{X} 5$ represents the ratio of sales to total assets. This ratio measures the ability of a firm's assets to generate sales.

Altman (1968:118) stipulates that the analytical range of the $\mathrm{Z}$ score, for the prediction of insolvency of privately-held retail firms, is as follows:

Less than 1.23 (high probability of insolvency);

1.23 to 2.90 (gray zone where insolvency is difficult to predict); and

Greater than 2.90 (low probability of insolvency).

The relevance of the interpretation of the $Z$ score, to this study, is that firms in the sample with $Z$ scores of less than 1.23 are regarded as insolvent. Firms with $\mathrm{Z}$ scores of between 1.23 and 2.90 are in the gray zone where insolvency is difficult to predict. Firms with $\mathrm{Z}$ scores of above 2.90 are solvent (Altman (1968:589).

The norms that will be used for this research are the ratios calculated by the Bureau of Financial Analysis (BFA) in Pretoria for the various sectors of the South African economy. BFA calculated the ratios on behalf of the South African Financial Sector Forum which is the umbrella organisation of all the financial institutions in South Africa. These ratios are relevant to the South African business environment and they will be compared with the ratios obtained from the respondents of this research. The ratios have been calculated for each of the thirty seven sectors on the Johannesburg Securities Exchange using a standardised system of analysis for all the listed firms (South African Financial Sector Forum, 2005).

\section{METHODOLOGY}

\section{Population and Sample}

A list supplied by the Food Marketing Institute revealed that there are approximately 300 grocery shops owned by black individuals in the Mdantsane area of East London (Food Marketing Institute, 2004:3). Spaza shops, hawkers and street vendors were not included in the list. The researcher, then, calculated a sample size using a rule of thumb that states that a sample size has to be a sixth of the sample population based 
on six standard deviations within a $99.73 \%$ confidence (Cooper and Schindler, 2003:20). Therefore, for a population of 300 , the sample is calculated as $300 / 6$ which results in 50 . The sample size of the study was found to be 50 respondents. A total of 36 questionnaires were returned indicating a response rate $72 \%$.

\section{Research Instrument}

The empirical research component of the study consisted of a self administered questionnaire. The study employed five point Likert scaled questions, multiple choice rating questions, dichotomous questions, open ended questions, open ended and single answer questions respectively. The questionnaire was pre-tested amongst five of the respondents identified in the sample to ensure reliability and validity.

\section{Validity}

The study adopted the approach of using the thirteen most common financial ratios to measure financial impact since they have been mostly used in literature and these ratios have been tried and tested (Karahanna and Chen 2004; Santhanam and Hartono,2003).

\section{Reliability}

Reliability refers to the degree to which measures are free from error and, therefore, yield consistent results (Zikmund, 2003:300). Terreblanche and Durrheim (2002:117) assert that the following errors pose a serious threat to the reliability of data, namely subject error and subject bias. The subject error was minimised by having the respondents filling the questionnaire in the presence of the researcher. Groves, Dilliman, Eltinge and Little (2002:32) support the above statement by arguing that the rule of thumb in the research industry is that a response rate above $50 \%$ is sufficient to minimise response bias. This study had a response rate of $72 \%$.

\section{Data Gathering}

The researcher visited grocery shops owned by black individuals in Mdantsane and administered questionnaires to the shop owners/managers. The researcher covered the area of study in 4 weeks, stretching from the period of 1 March 2005 to 31 March 2005. Approximately 30 minutes were required to complete the questionnaire.

\section{Data Analysis}

TThe researcher was able to use statistical techniques of inference to test the hypotheses. This was primarily based on the software package MINITAB Release 14 . MINITAB Statistical Software is a comprehensive statistical tool for managing, analysing and displaying information. Among the features available are the management and manipulation of data and files, producing graphs, analysing data, assessing quality design, experiment and generate reports (Anon, 2005). Based on the distribution of the descriptive statistics for this study, a normal distribution was used to perform the inferential analysis such as 'ANOVA One Way'.

\section{RESULTS}

Table 1.1 A comparison of performance measures and ratios for the retail sector

\begin{tabular}{|l|r|r|}
\hline $\begin{array}{l}\text { Performance } \\
\text { Measure }\end{array}$ & $\begin{array}{r}\text { Results from } \\
\text { the study }\end{array}$ & $\begin{array}{r}\text { Listed } \\
\text { Retailers }\end{array}$ \\
\hline $\begin{array}{l}\text { Liquidity and } \\
\text { Solvency structure }\end{array}$ & & \\
\hline Current ratio & 1.21 times & 1.72 times \\
\hline Quick ratio & 0.59 times & 1.22 times \\
\hline Debt to assets & $63.3 \%$ & $52 \%$ \\
\hline Debt to equity & 1.72 times & 1.08 times \\
\hline $\begin{array}{l}\text { Profitability } \\
\text { structure }\end{array}$ & & \\
\hline Operating Margin & $4.17 \%$ & $8.86 \%$ \\
\hline Net Profit Margin & $4.0 \%$ & $5.72 \%$ \\
\hline Return on Assets & $12.793 \%$ & $16.88 \%$ \\
\hline Return on Equity & $15.02 \%$ & $21.56 \%$ \\
\hline Total Asset Turnover & $1.3 \%$ & $1.90 \%$ \\
\hline
\end{tabular}

Source: Figures for listed retailers adapted from (South African Financial Sector Forum, 2004:35)

\section{Liquidity and Solvency structure}

The following ratios, namely current ratio, quick ratio, debt to assets and debt to equity will be discussed under this section.

\section{Current ratio}

The current ratio of the retailers, in Mdantsane, indicated that the measurement ratio of 1.21 times is below that of listed retailers of 1.72 times and below the acceptable $2: 1$ norm set by financial statisticians. This implies that the grocery shops, in the study have $\mathrm{R} 1.21$, of current assets to meet R1.00 of its current liabilities. The results of this ratio indicate that the respondents may find it difficult to meet debt obligations as they become due as a result of inadequate cover exhibited above. However, this does not show that the respondents are technically insolvent, because 
their current assets are higher than their current liabilities. Technical insolvency is described as a situation where a firm's current assets are lower than its liabilities.

The quick ratio is to be computed next, as it gives a more realistic picture of a business's ability to repay current obligations than the current ratio as it excludes inventories and prepaid items for which cash cannot be obtained immediately. This ratio is usually used as a supplement to the current ratio.

Quick ratio

The grocery shops in the study also have a low ratio of 0.59 compared to 1.22 of the listed retailers, and more so of the norm $1: 1$ set by financial statisticians. The quick ratio is an indicator as to whether a firm can pay current liabilities without relying on the sale of inventory. The 0.59 quick ratio of Mdantsane retail firms implies that they will not be able to meet current liabilities without selling inventory.

The use of debt by small firms in Mdantsane will be assessed next.

Debt to assets

The mean debt to assets ratio, for this study, was $(63.3 \%)$, which implies that retail firms in the survey are insolvent. This result indicates that the assets of small retail firms are financed more by creditors than by their owners. The result, in addition, indicates that small firms rely more on debt than equity in their capital structures. The findings of this study also support previous South African studies by Rwigema and Karungu (1999:107) and Reekie, Lingard and Cohen (1996:10) who determined that SMMEs, in South Africa, rely heavily on debt financing to ensure their future survival.

Debt to equity

The debt to equity of Mdantsane retail firms is 1.72 times, and is in excess of the listed retailers which are at 1.08 times. This supports the views of previous research by Brigham (2003:11), in America, who established that small firms use more debt than large firms. This observation implies that the debt situation is not peculiar to small retail firms in South Africa alone. However, it is worth noting that the use of debt, ultimately, impacts on the profitability structure of the business, as interest, for example, needs to be paid out of the profits.

\section{Profitability structure}

The following ratios namely, operating margin, net profit margin, return on assets and return on equity will be discussed under this heading.

\section{Operating Margin}

Operating margin equals operating profits (EBIT) divided by sales, and is expressed as a percentage (Gitman, 2003:127). The percentage represents the amount of each rand of revenue that results in operating income. A higher percentage is better since it implies expenses are low and earnings are high. In this regard, the retailers in Mdanstane are performing poorly when compared to listed retailers, as they have a percentage of 4.17 compared to that of listed retailers which is at 8.86 .

\section{Net Profit Margin}

Net profit margin is calculated by dividing net profit after taxes by sales (Gitman, 2003:129) often expressed as a percentage. This percentage is an indication of how effective a company is at cost control. The higher the net profit margin is, the more effective the firm is at converting revenue into actual profit. The net profit margin ratio shows investors the amount of net profit per R1 of turnover a business has earned. That is, after taking account of the cost of sales, and all costs associated with running a retail firm. The retail firms, in Mdantsane, at a net profit margin of $4.0 \%$, also lagged behind in converting revenue into actual profits when compared with listed retailers by $5.72 \%$.

\section{Return on Assets}

Return on assets measures a firm's earnings in relation to all of the resources it had at its disposal (the shareholders' capital plus short and long-term borrowed funds). If a company has no debt, the return on assets and return on equity figures will be the same. The average return on assets (ROA) percentage of the study $(12,79 \%)$ is rather low even when compared with listed grocery retailers who had a return on assets of $16.88 \%$ for 2004 . This ratio indicates the profitability of the business and its efficiency in using its assets. In other words, capital productivity is, rather, low for the grocery shops in the study.

Return on Equity

Return on Equity represents a measure of a firm's profitability, calculated by dividing net profits after taxes by shareholder's equity. Essentially, ROE reveals how much profit a company generates with the money shareholders have invested in it and is also known as Return on Net Worth (RONW). The Mdantsane firms, in the study, had a return on equity of $15.02 \%$, and the listed firms had a return of $21.56 \%$. This is in line with studies by Ranft (2001:126) and Rizik (2001:16) who have suggested that small retailers need to concentrate on profitability. However, Ackerman 
(2005:18) stipulated that, "sell a thousand tins of beans with one percent profit on each tin, and you bank a thousand cents'. Therefore, although the percentage on tins of beans might be lower, the contribution to profits might be higher". He, further, remarks that you don't bank percentages - you bank money. However, to implement what Ackerman indicated above a firm needs a high volume of customers that is unlikely in Mdantsane. Lower profitability contributes to the undercapitalisation problem because it leads to fewer rands of retained earnings and therefore to a reliance on external capital (Correira et al., 2003.ch20, p.10).

Total Asset Turnover

The results show that the total asset turnover of the retailers in Mdantsane is 1.30 times larger than total assets. This implies that the retail firms in Mdantsane were able to generate sales of R1.30 for every R1 of assets it owned and used for the year. However, the total asset turnover is lower by 0.60 when compared to that of listed retailers of 1.90 . This implies that retailers, in Mdantsane, have not been able to generate more income from their invested capital than listed retailers.

The data collected from the respondents regarding all the above ratios were subjected to further statistical tests using the Multiple Discriminant Analysis (MDA). The calculated $\mathrm{Z}$ scores for the respondents was 2.58 which imply that small firms in Mdantsane are in the gray zone where insolvency is difficult to predict.

\section{Financial Management}

This was also covered in some depth in the study. One set of the questions was intended to establish the degree of sophistication of the financial information that was available to owners; and whether they maintained separate personal and business accounts, regarded as the minimum level of prudency in the management of finances. The respondents were also asked to indicate where they obtained the financial information used to answer the questionnaire. This enabled the researcher to verify the accurateness of the information presented.

The findings also indicated that retailers in Mdantsane do not have a sophisticated means of collecting financial information. The study results further reveal that managers/owners prepare financial statements to assist them with negotiations with third parties such as banks instead of monitoring the performance of the business. According to the study, the majority (69\%) of the retailers, in Mdantsane do not keep separate bank accounts. This implies that business and personal funds are kept in one account which exposes the retail firms to the risk of over-withdrawals by owners. Furthermore, it was also revealed that retailers, in Mdantsane, are slow payers of accounts.

The study also revealed that retailers, in Mdantsane, have a lack of capital which impairs their ability to embark on vigorous marketing campaigns. The study, also, established that it is difficult for the owners/managers of small firms to acquire funds to support their business. The study also revealed that $31 \%$ of the borrowed funds go into the working capital management activities such as the purchasing of stock. This implies that small retail firms, in Mdantsane, will have little funds left to embark on marketing related activities.

In order to test the hypothesis that states that variables that impinge on the performance of grocery shops are amongst others, bad debts and excessive withdrawals. ANOVA (Analysis of variance), as well as a regression analysis was employed to test statistically, the significance of this assertion. When tested at a 5\% level of significance, it was discovered that financial management on the overall plays a significant role in determining profitability. This can be seen from the p- value of 0.00 (refer to exhibit 1) which indicates the significance of the model.

The following factors, namely keeping of separate bank accounts (0.008), application of loaned funds (0.032) and having a budget $(0.017)$ were found to have a significant effect on net profit as an indicator of business performance. The study results indicate that prudence in the management of cash resources, the keeping of separate bank accounts and budgeting, in particular, are important for the small retail firm since, it can be used as the benchmark against which retailers of any size can, accurately, forecast cash flows and track performance. The overall model shows a significant relationship between net profit and the three variables mentioned above; namely, keeping of separate bank accounts (0.008) application of loaned funds and having a budget. 


\section{CONCLUSION}

It is imperative that the management of small firms improve their managerial skills on aspects of financing, financial information preparation, and the calculation of capital requirements. Grocery shops have struggled to obtain adequate and appropriate finance. The vast majority of respondents (75\%) said that commercial banks are discriminating by rejecting their requests for credit facilities. Other reasons given by the respondents included a lack of acceptable security and a lack of understanding by the banks. It is recommended that commercial banks study these reasons offered by the respondents as to why they feel that their credit applications are rejected. Commercial banks should devote a strategy for assisting grocery shops to understand the requirements for loan applications. This will enable the grocery shop owners to understand what is expected of them by the commercial banks when requesting for loans. It is, furthermore, recommended that commercial banks undertake a substantial public awareness campaign on their requirements from grocery shops that intend to request for credit.

\section{EXHIBIT}

\section{ANOVA}

\begin{tabular}{|ll|c|r|r|r|r|}
\hline Model & & $\begin{array}{c}\text { Sum of } \\
\text { Squares }\end{array}$ & $\mathrm{df}$ & Mean Square & $\mathrm{F}$ & Sig. \\
\hline 1 & Regression & $3.06 \mathrm{E}+11$ & 7 & $4.374 \mathrm{E}+10$ & 9.126 & $.000^{a}$ \\
& Residual & $1.34 \mathrm{E}+11$ & 28 & 4792658360 & & \\
& Total & $4.40 \mathrm{E}+11$ & 35 & & & \\
\hline
\end{tabular}

a. Predictors: (Constant), BUDGET, FININFO, BILLS, FINFOP, ESYAC, APPLIC, BANKACC

b. Dependent Variable: NETP

\section{Coefficients $^{\mathrm{a}}$}

\begin{tabular}{|c|c|c|c|c|c|c|}
\hline \multirow[b]{2}{*}{ Model } & & \multicolumn{2}{|c|}{$\begin{array}{c}\text { Unstandardized } \\
\text { Coefficients }\end{array}$} & \multirow{2}{*}{$\begin{array}{c}\text { Standardized } \\
\text { Coefficients } \\
\text { Beta }\end{array}$} & \multirow[b]{2}{*}{$t$} & \multirow[b]{2}{*}{ Sig. } \\
\hline & & $\mathrm{B}$ & Std. Error & & & \\
\hline \multirow[t]{8}{*}{1} & (Constant) & 402459.7 & 129313.3 & & 3.112 & .004 \\
\hline & FININFO & -9666.839 & 5873.283 & -.184 & -1.646 & .111 \\
\hline & FINFOP & -16938.1 & 10598.104 & -.188 & -1.598 & .121 \\
\hline & BANKACC & 30616.294 & 10711.737 & .428 & 2.858 & .008 \\
\hline & BILLS & 52471.258 & 27389.135 & .231 & 1.916 & .066 \\
\hline & APPLIC & -47970.5 & 21289.179 & -.315 & -2.253 & .032 \\
\hline & ESYAC & 4686.667 & 8763.319 & .066 & .535 & .597 \\
\hline & BUDGET & -63405.2 & 25039.956 & -.335 & -2.532 & .017 \\
\hline
\end{tabular}

a. Dependent Variable: NETP 


\section{REFERENCES}

Ackerman, R. (2005), Four legs of the Table: The story of Raymond Ackerman as told to Denise Prichard, Cape Town, David Philip Publishers.

Anonymous. (2005), MINITAB Release14 Statistical Software for Windows [On-line]. Ava liable: http://www.minitab.

com/products/minitab/14/default.aspx [Accessed: 1 Mar.2005]

Anonymous. (2006a), Driving Business Performance: Implementing New Metrics and Incentives [On- line]. Available:

http://www.irc.caltech.edu/courses/Business

Performance_Metrics_Measurement.htm [Accessed: 2 July.2006].

Altman, E. I., (1968), "Financial Ratios, Discriminate Analysis and the Prediction of Corporate Bankruptcy", The Journal of Finance, 4(8):589-609.

Brigham, E.F., (2003), Fundamentals of Financial Management, Cincinatti, Thomson Learning.

Cant, M.C. and Brink, A., (1999). "Black Retailing" The International Scope Review Volume 1, Winter1. [On-line].Available:

www.socialcapitalfoundation.org/journal/volume $\% 2$ 01999/issue2/pdf/Cant\&Brink.pdf [Accessed: 24 March 2004].

Competition Tribunal Republic of South Africa, (2000), Competition in Africa [On-line]. Available: www.comptrib.co.za/decidedcases/pdf/46LMSep03. pdf [Accessed: 2 Apr. 2004].

Cooper, D.R. and Schindler.P., (2003), 8th, Business Research Methods, New York, McGraw-Hill.

Correira.C, Flynn.D, Uliana.E, and Wormland.M, (2003), 5th, Financial Management, Lansdowne, Juta and Company Ltd.

Gitman, L. J. (2003), Principles of Managerial Finance. MA, Addison Wesley Longman.

Food Marketing Institute, (2004), Facts and Figures. [On-line].Available: http [Accessed: 25 March .2004].

Groves, R.M, Dilliman. D.A, Eltinge. J.L and Little. R.J. (2002), Non- Response in Survey Methodology, New York, John Wiley and Sons Inc.

Karahanna, E., and Chen, D. (2004), "High Performing CIOs and Firm Performance: Give your CIO Time." Unpublished working paper.

Ranft, A. L. (2001), 'Board composition and highflying founders: Hints of trouble to come?', Academy of management executive, vol. 15 , no. 1 pp. 126-138.

Reekie, W.D, Lingard, G.S. and Cohen, M.B. (1996), Elements of South African Business Finance.

Johannesburg: Southern Publishers.

Rode Property Economists Consultancy and Valuers, (2004), Retailer shop lies in the small trader [On-line]. Available: http [Accessed on 21April 2004].

Rwigema, H. and Karungu, P. (1999), 'SMME Development in Johannesburg's Southern Metropolitan Local Council: An Assessment'. Development Southern Africa 16(1): 107-124.

Santhanam, R., and Hartono, E. (2003), "Issues in Linking Information Technology Capabilities to Firm Performance." MIS Quarterly 27(1): 125-153.

South African Financial Sector Forum (2004)., Economic Data and Forecasts [On- Line]. Available: http://www.finforum.co.za/econdata.htm. [Accessed: 6 June 2004].

South African Government, (1995), Address to the President's Conference on Small Business, Durban 28 March [On- Line].Available: http://www.polity.org.za/html/govdocs/ white papers/smallbiz.html?rebookmark=1. [Accessed: 30 March 2004].

Steinhoff, D. and Burger, F, (1996), Small business management fundamentals, New York, McGraw-Hill.

Terreblanche, M. and Durheim.K, (2002), Research in practice: Applied Methods for social sciences, Cape Town, University of Cape Town.

Venktraman, N., and Vasudevan, R. (1986),

"Measurement of Business Performance in Strategy Research: A Comparison of Approaches." Academy of Management Journal: 801-814.

Zikmund, W.G .2003.7th. Business Research Methods, Australia, Thomson South-Western. 